\title{
Implementation of Centralized Networking System and Integrated Marketing Communication for MSMEs in Buah Batu Bandung
}

\section{Implementasi Sistem Jaringan Terpusat dan Komunikasi Pemasaran Terpadu Bagi UMKM di Buah Batu Bandung}

Astri Wulandari ${ }^{1, *)}$, Bethani Suryawardani ${ }^{1}$, Dandy Marcelino ${ }^{2}$, Gandeva Bayu Satrya ${ }^{3}$, Fat'hah Noor Prawita ${ }^{3}$, Wahyu Lukito ${ }^{4}$, Bijaksana Prabawa ${ }^{4}$

${ }^{1}$ Marketing Management, School of Applied Science, Telkom University, Bandung

${ }^{2}$ Master of Management, School of Economy and Business, Telkom University, Bandung

${ }^{3}$ Application Software Engineering, School of Applied Science, Telkom University, Bandung

${ }^{4}$ Visual Communication Design, School of Creative Industry, Telkom University, Bandung

${ }^{*}$ Corresponding author: astriwulandari@telkomuniversity.ac.id

Diterima: 22 November 2021 | Disetujui: 1 Desember 2021 | Publikasi Online: 10 Desember 2021

\begin{abstract}
Network security is very important, especially for community service units because a damaged system can affect other systems. Therefore, it is necessary to design and develop a computer network system and security that's more centralized. Promotional activities are very important to be carried out by every business from the smallest scope to even large companies, because no matter how good the quality of the products the company has, it will not be successful for sale without proper promotion. Referring to the situation and problems faced by partners, our group took the initiative to contribute by providing several alternative solutions whose goals are expected to be useful for partners, by providing training on the implementation of integrated networks and MSME database management, then providing an integrated marketing communication training, workshop on communication marketing tools that can provide a competitive advantage for MSMEs so that MSME marketing tools in Buah Batu District have superior value. With some of the solutions that we offer, the expected final results from this community service activity are network problems and database management can be resolved properly. Furthermore, MSMEs in Buah Batu District have standardized and attractive printed and digital marketing tools.
\end{abstract}

Keywords: Centralized networking system, communication marketing tools, digital communication, MSMEs

\section{ABSTRAK}

Keamanan jaringan sangat penting terutama bagi unit pelayanan masyarakat karena sistem yang rusak dapat mempengaruhi sistem lainnya. Oleh karena itu, perlu dirancang dan dikembangkan sistem jaringan komputer beserta keamanannya yang lebih baik dan terpusat. Kegiatan promosi sangat penting dilakukan oleh setiap bisnis dari lingkup terkecil bahkan perusahaan besar, karena sebaik apapun kualitas produk yang dimiliki perusahaan tidak akan berhasil dijual tanpa promosi yang tepat. Merujuk pada situasi dan permasalahan yang dihadapi mitra, kelompok kami berinisiatif untuk berkontribusi dengan memberikan beberapa alternatif solusi yang tujuannya diharapkan dapat bermanfaat bagi mitra yaitu di bidang IT dengan memberikan pelatihan penerapan jaringan terintegrasi dan manajemen database UMKM, kemudian dengan memberikan pendampingan komunikasi pemasaran terpadu, workshop alat komunikasi pemasaran yang dapat memberikan keunggulan kompetitif bagi UMKM sehingga pemasaran UMKM di Kecamatan Buah Batu memiliki nilai yang unggul. Dengan beberapa solusi yang kami tawarkan, hasil akhir yang diharapkan dari kegiatan pengabdian masyarakat ini adalah masalah jaringan, pengelolaan database dapat teratasi dengan baik, dan UMKM di Kecamatan Buah Batu memiliki alat pemasaran cetak dan digital yang terstandar dan menarik.

Kata kunci: Sistem jaringan terpusat, komunikasi pemasaran terintegrasi, komunikasi digital, UMKM

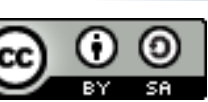

Content from this work may be used under the terms of the Creative Commons Attribution-ShareAlike 4.0 International. Any further distribution of this work must maintain attribution to the author(s) and the title of the work, journal citation and DOI.

Published under Department of Communication and Community Development Science, IPB University and in association with Perhimpunan Ahli Penyuluhan Pembangunan Indonesia.

E-ISSN: 2442-4110 | P-ISSN: 1858-2664 



\section{INTRODUCTION}

Empowering Micro, Small, and Medium Enterprises (MSMEs) is highly crucial because of its enormous potential in driving community economic activities while also serving as the primary source of income for most people in improving their well-being. The role of MSMEs in increasing income and employment can certainly be considered large for Indonesia (Hartono \& Haniya, 2018). Micro, small and medium enterprises (MSMEs) are part of national businesses that play an important role in realizing national development goals. MSMEs can also be considered as the locomotive of national and regional economic growth, because they have the potential to empower all existing resources and encourage the growth of entrepreneurship development (Sari et al., 2016).

MSME products in Buah Batu District consist of various types of products that have the potential to attract local and foreign tourists visiting Bandung City, but based on the observations, these MSME's products have not yet had brand awareness and the promotion tools that meet standards such as incomplete product information, unattractive promotional designs, inappropriate use of media, and so on. Based on this research outcomes, we will take an initiative to provide workshops for MSME actors so that the resulting product is expected to have value and be able to compete with other products. Buah Batu District is located on Cijawura Hilir Street, Number 291, Margasari Village, Buah Batu Subdistrict, Bandung City, West Java 40287. Buah Batu Subdistrict is divided into 4 (four) villages, namely Margasari Village, Cijawura Village, Sekejati Village and Jatisari Village.

MSMEs in Buah Batu District have not yet had high competitiveness. Business scale, productivity and level of technology application are factors that affect the competitiveness of MSMEs (Prasanna et al., 2019). Due to the fact that in Indonesia many MSMEs are still doing production, marketing and promotion traditionally, and they do not take advantage of technological sophistication. This is due to several things, one of which is the limitations of MSME actors in terms of building information technology independently in addition to the high price when buying (Clegg, 2018).

To avoid being trampled over by competition, organizations all over the world must constantly reinvent their tactics. By innovation, the organization will gain a competitive advantage over competitors (Kuncoro \& Suriani, 2018). Competitive advantage refers to the use of information in order to gain strength or impetus (increase) in the market (Autio, 2017). One of the most effective innovations for gaining a competitive edge is to incorporate information technology into current organizational processes (Jabbar et al., 2019). It must be recognized that the advancement of information technology has altered the way people live in the world and carry out their everyday tasks. Information technology is a branch of technology concerned with the transformation of data into information and the process of disseminating data/information within the constraints of space and time (Fonseca et al., 2020).

Network security is very important, especially for community service units because a damaged system can affect other systems (Elrawy et al., 2018; Frustaci et al., 2018; Urquhart \& McAuley, 2018). Therefore, it is necessary to design and develop a computer network system and its security that is better and more centralized (Li et al., 2018; Qiu et al., 2018; Ul Hassan et al., 2019). The integration of the computer network needed for Buah Batu District is very necessary and must be designed as well as possible to make it easier if there is a development or continuation of the existing system into a more reliable system. Providing training in database system management to facilitate maintenance and further development is also important. Regarding the network problems, the team will provide training on how to maintain and configure the network to be more optimal.

Promotional activities are very important to be carried out by every business from the smallest scope to even large companies, because no matter how good the quality of the products the company has, it will not be successful for sale without proper promotion (Camilleri, 2018; Ducange et al., 2018; Razak et al., 2020). Promotional media consists of two types, namely printed promotion tools and digital promotion tools (Briandana \& Dwityas, 2020; Pramanik \& Rakib, 2020; Prihadini et al., 2020), but good companies need to integrate several alternative promotion tools so that their promotions can reach the right target (Key \& Czaplewski, 2017; Martin, 2017; Villanova et al., 2021). SMEs in Buah Batu District need to be given training and workshops on integrated marketing communication that can be implemented on their respective products.

Marketing communication is a means for organizations or institutions to inform, invite, and remind consumers directly or indirectly about products and services (Qian et al., 2019). Marketing communications represents the voice of organizations and institutions and are a means of creating 
dialogue and building relationships with consumers (Schmeltz \& Kjeldsen, 2019). The first communication is a process of thinking and understanding transmitted between people or between organizations and individuals, and the second communication is a process of thinking and understanding conveyed between organizations and individuals (Fraccastoro et al., 2021). Communication is the process of sending messages that are the sender's ideas or information to the receiver via a medium in order for the recipient to grasp the sender's goal (Fjeldstad \& Snow, 2018). The second main element is that marketing is a set of organizational or institutional activities to transfer values or exchange of information on products, services and ideas between them and their customers (Fraccastoro et al., 2021).

Integrated marketing communications is a concept in marketing communication planning that recognizes the added value of a comprehensive plan that evaluates the strategic role of various communication disciplines such as general communications, direct response, sales promotion, and public relations and combines these disciplines to provide maximum clarity, consistency, and impact of effective communication through the comprehensive integration of disparate messages (Kembau et al., 2019; Sulaeman \& Kusnandar, 2020).

According to Ganlin et al (2021) study, MSMEs must enhance their competitiveness and the competitiveness of their goods in order to survive on and capitalize possibilities. The company's rising competitiveness will stimulate the development of product competitiveness. Another objective for MSMEs should be to improve collaboration between MSME units or between MSME centers, as well as to expand cooperation networks with stakeholders because stakeholders' support in the form of education/training/counseling, promotion, and other facilitation has been shown to promote initiatives to develop human resources. In fact, SMEs' competitiveness has increased considerably.

Despite their contribution to the national economy, Micro, Small, and Medium Enterprises continue to confront a variety of internal and external hurdles and restrictions in terms of production and processing, marketing, human resources, design and technology, capital, and business climate (Badini et al., 2018). In this case, MSMEs still really need supporters to increase competitiveness. There needs to be intensive collaboration between local MSEs and universities, educational/training institutions and local R\&D so that there is a transfer of technology and knowledge to MSMEs. The role of stakeholders can be replaced with academics, practitioners, students (supporters) who will help SMEs according to their respective expertise. Vătămănescu et al. (2020) stated that the usage of IT has a favorable impact on organizational management strategies relating to communication, information access, decision making, data management, and knowledge management.

There were several problems encountered by the MSMEs in Buah Batu which can be described as follows. There is not yet integrated computer network service units in Buah Batu, Bandung, making it difficult for users and causing slow service to the community, because the competence of IT employees in the Buah Batu sub-district is not yet qualified with regard to network maintenance. Then the website of the Buah Batu sub-district has not been integrated with several supporting applications such as population applications, online complaint services, social media, and other applications. The database owned by Buah Batu District has not been integrated with a number of demographic apps or websites, and cannot be automatically updated. The next problem is the lack of understanding of MSME actors in Buah Batu District about integrated marketing communication. Media and promotional tools for MSME products in Buah Batu District, both printed and digital, are not attractive enough and do not meet the ideal standards. There is no website that contains profiles of superior products in Buah Batu that can increase brand equity and competitive advantages of MSME products.

Based on the problems that partners have as described above, researchers want to measure the research objective based on several solutions which are divided into three areas, namely IT, marketing and design. IT team will explore how the implementation of integrated network and database management and network security can be useful for IT staff in building a reliable and updated database system. In addition, the mentoring process carried out by the marketing and design team aims to identify the integrated marketing communications and the best marketing communication tools for MSME actors in the Buah Batu sub-district, which is expected to increase the competitive advantage of MSME products so that they will have high value. 


\section{METHODOLOGY}

This research is a part of basic or fundamental research because it mainly aims to gain more knowledge and understanding of the phenomena that occur, especially in the scope of product/service marketing. In general, the basic research is directed at efforts to develop and discover theories as the basis for scientific development (Peffers et al., 2018). This study employs critical and philosophical theory studies in order to provide knowledge and practice of marketing communication (Moisander et al., 2020). The descriptive research approach was used for this qualitative study. The data gathered is collated, explained, and then analyzed using a descriptive analytic technique, which tries to characterize a phenomena by doing research on specific elements linked to the phenomenon under study and comparing one factor to another (Castleberry \& Nolen, 2018).

This research is also intended to find out the nature of something with a proportion analysis approach that reveals the statement of the nature of reality using ex post facto data, means data collected after all events take place (Bellini et al., 2020). Data collection methods that will be used in this study are literature and interview methods. The literature method is collecting data through journals, papers and readings that are related to the research title (Azungah, 2018). The literature method has been chosen because the data and information needed are already available through research that has been published online and in print.

The location for the implementation of activities is carried out according to the following stages. The first activity, namely the coordination of the community service team, was carried out at the Faculty of Applied Sciences. The activities carried out included discussions on training preparation, evaluation of activity achievements, discussion of the results of analysis and application design and application testing. The second activity, namely surveys, interviews for data collection, data requests and coordination of training participants, as well as functionality needs were carried out at the Buah Batu District Office. The next activity in the form of training and workshops was held at Buah Batu District Hall, Bandung, which is located at Cijawura Hilir Street, Number 291, Margasari, Buah Batu, Bandung, West Java.

The method of implementing community service that will be carried out includes the following stages. First step is data collection, the data is needed to get an overview of the existing conditions by conducting interviews and forum group discussions (FGD) with the Head of Sub-district and related Division Heads (Adhabi \& Anozie, 2017; Archibald et al., 2019; Hennink et al., 2019). With this technique, data are obtained in the form of: 1) profile of SMEs and target communities; 2) real problems faced by each target community; and 3) the functional/feature requirements that the Buah Batu sub-district website must have for complete and integrated data management and community profiles.

The second step is network analysis and design and promotional media. Analysis was performed to: a) describe each business process to be evaluated in order to obtain a complete picture of the current condition and to identify problems that occur; b) identify functionality requirements as a reference in determining the features that must be owned by the website being built; and c) design promotion tools and content that will be included in the promotional media that will be created (Evermann et al., 2017; Gonzalez-Granadillo et al., 2018; Hussain et al., 2018). The design was carried out for modeling functionality, creating database design, and creating design and promotional content (Hsu et al., 2018; Naum et al., 2017; Radianti et al., 2020).

The third step is website creation, testing, and documentation. This step involves developing the software to create a website based on the design; testing the application to check all functionality to run properly; and documenting the website to create a user manual (Gao et al., 2019; Harris et al., 2019; Lu et al., 2017). The fourth stage is to socialize application usage. This step is completed to teach all users on how to utilize the website and to socialize it with interested parties (Leidner et al., 2018; Wandasari et al., 2019). And the last step is training and workshops by providing integrated marketing communication training and marketing tools workshops for MSME actors in the Buah Batu District, Bandung.

Jurnal Penyuluhan | Vol. 18 (01) 2022 | 15 


\section{RESULTS AND DISCUSSION}

In light of the conditions and issues that our partners are experiencing, our group has proposed many alternative options that are likely to be beneficial for public services and MSMEs in Buah Batu District in particular and the entire community in Buah Batu District in general. The alternative solutions are as follows:

1. Build an integrated computer network system in service units in Buah Batu District and then provide training on network maintenance and database management for IT staff in every village under the auspices of Buah Batu District, Bandung.

2. Provide integrated marketing communication training for MSME actors in Buah Batu District, Bandung which can help partners to increase brand awareness of MSME products, provide workshops on marketing communication tools, and design promotional media for superior products in Buah Batu District.

The implementation of community service in Buah Batu District has been carried out in an orderly and smooth manner with two groups of target partners. The first target partners were SMEs in the Buah Batu District, Bandung, which was attended by 16 participants. The second target partner was the IT staff at the Buah Batu District and other offices under the auspices of the Buah Batu District, which was attended by 10 IT staff.

Integrated marketing communication training and workshop was attended by MSME actors and presenters from the marketing team and the design team. Participants were given material on integrated marketing communication that can be applied as a promotion of alternative strategies that can be applied in the products they market. In addition, the design team provided material on increasing brand awareness through brand communication as well as reviews on packaging and provided input on promotional media that had been carried out by MSME actors. The output of the activity was that the design team helped design promotional media and packaging for three MSMEs.

Various elements in integrated marketing communication (IMC) have been carried out by large companies. The MSMEs are no exception. MSMEs can carry out integrated marketing communications, although not optimally. Promotional activities carried out by MSMEs are still constrained by costs, as stated by (Wetik et al., 2019), the very minimal promotional ability is caused by the absence of costs. The following are some elements in integrated marketing communication that can be applied by SMEs.

1. Advertisement is a form of non-personal or mass presentation and promotion of ideas, goods and services in the mass media paid for by a particular sponsor (Elihanov \& Matygov, 2020). The advantages of advertising are the low cost of each ad appearance (low cost per exposure), varied media, the ability to control each ad appearance (control of exposure), consistent message content and the opportunity to design creative messages. In addition, the appeal and message can be adjusted as the purpose of the communication changes. The disadvantage of advertising is that there is no direct interaction with buyers. And the message content also tends to stay for a certain period or duration. In the application in MSMEs, advertising that can be carried out in accordance with the limited funds available is advertising via radio, distributing leaflets or brochures and installing banners. Brochures can be distributed to introduce marketed products. The distribution of brochures can be carried out several times according to the existing budget and the evaluation results from the distribution of previous brochures. Like brochures, banners can also be used to introduce products to consumers. Banners can be installed in strategic and crowded places.

2. Publicity or Public Relations (PR) is the non-personal stimulation of the demand for goods, services, ideas, etc., with meaningful commercial news in the mass media and is not paid to promote and/or protect the image of a company or its individual products (Ferguson, 2018). PR builds good relations with the various publics of the company by obtaining favorable publicity, establishing a good corporate image and dealing with or eliminate rumors, stories and unfortunate events. The advantage of public relations lies in cost efficiency because the company does not pay for the mass media as a means of promotion. However, negative publicity can have a negative impact on the company. 
MSMEs can take advantage of publicity by creating news with special characteristics to attract journalists to write articles about their products. Introducing products to consumers without paying to the mass media is a way that can be used when considering the limited funds for promotion.

3. Sales promotion consists of short-term incentives to encourage the purchase or sale of a product. While advertising and personal selling offer reasons to buy a particular product, sales promotion offers reasons to buy now (Eleboda, 2017). Thus, sales promotion is defined as a short-term incentive in promotional activities to stimulate the purchase of a product in various ways, such as trade shows, sales incentives, coupons and so on. Sales promotion should create consumer relationships, not just short-term sales or contemporary brand switching. Sales promotion should help strengthen the product's position and create long-term relationships with consumers. Consumer promotion tools include product samples, coupons, cash refunds, price sets, premium gifts, special advertising, customer rewards, point-of-purchase exhibitions and demonstrations, and contests, sweepstakes, games. Trade promotion tools are direct discounts, perks and freebies. MSMEs can implement sales promotions by choosing one or several existing promotional tools; for example: giving a discount, which is giving one unit free if you buy ten units, or providing product samples for free. In addition, MSMEs can participate in various expos or trade fairs, whether conducted by the government or the private sector, is also

4. Direct marketing is a form of promotion by using letters, telephone, facsimile, e-mail and other nonpersonal contact tools to communicate directly with or get direct responses from certain customers and prospective customers (Farhana et al., 2020). Direct marketing consists of direct relationships with carefully targeted individual customers both to obtain an immediate response and to foster long-lasting customer relationships. Direct marketers communicate directly with customers often on a one-to-one and interactive basis. Using a detailed database, they design offerings and marketing communications that are able to respond to the needs of narrowly defined segments or even individual buyers. More than just developing a brand and image, they are usually looking for direct, immediate and measurable customer feedback. Despite these challenges, large and small companies (MSMEs) are rapidly integrating online marketing into their marketing mix. As the effort continues to grow, online marketing will prove to be a powerful tool for building customer relationships, increasing sales, communicating company and product information, and delivering products and services more efficiently and effectively. The implementation of integrated marketing communications in MSMEs is not an integrated system, but is a promotional program that is reactively prepared according to available funds. As stated by (Porcu et al., 2020), in implementing the concept of integrated marketing communication, there are several obstacles, namely: lack of horizontal communication, functional specialization, decentralization, lack of IMC planning, lack of funds, lack of database technology, corporate culture and fear of change. However, this integrated marketing communication program that can be compiled by MSMEs is simply designed for the purpose of communicating their products to consumers more broadly.

To obtain an overview of the system to be designed, it is necessary to analyze several literature sources that have been carried out. Problem analysis is carried out to identify the problems that have been described in the previous stage. These problems are based on a literature study conducted by researchers. Meanwhile, MSMEs in the Buah Batu area lack competitiveness, beginning with internal aspects such as manufacturing and processing, marketing, human resources, and design. Meanwhile, high competitiveness is required to compete in the global market, therefore MSMEs in this instance absolutely need supports to enhance competitiveness.

The initial investigation was the stage where the researcher did a literature study of previous research to generate information. Despite the fact that the cost of information technology was becoming more inexpensive, it remained a costly item for most MSMEs owing to budgetary constraints and a lack of experience in utilizing their own computers (Wilson \& Makau, 2018). In this condition, it is necessary to have a close cooperation between local MSMEs and universities, educational/training institutions and local R\&D so that there is a transfer of technology and knowledge to MSMEs (Rodríguez-Soler \& Brunet Icart, 2018). 
Centralized network system training was conducted by the IT team with participants from IT staff in Buah Batu District. The training material is about network security and augmented reality technology that can be applied in public services. In addition, the output of this activity is to build new features in the web service application of Buah Batu sub-district. The new features consist of: file a damaged eKTP report; file a lost e-KTP report; applying for family card renewal; accessing lost e-KTP report files; accessing corrupt e-KTP report files; and accessing family card update files.

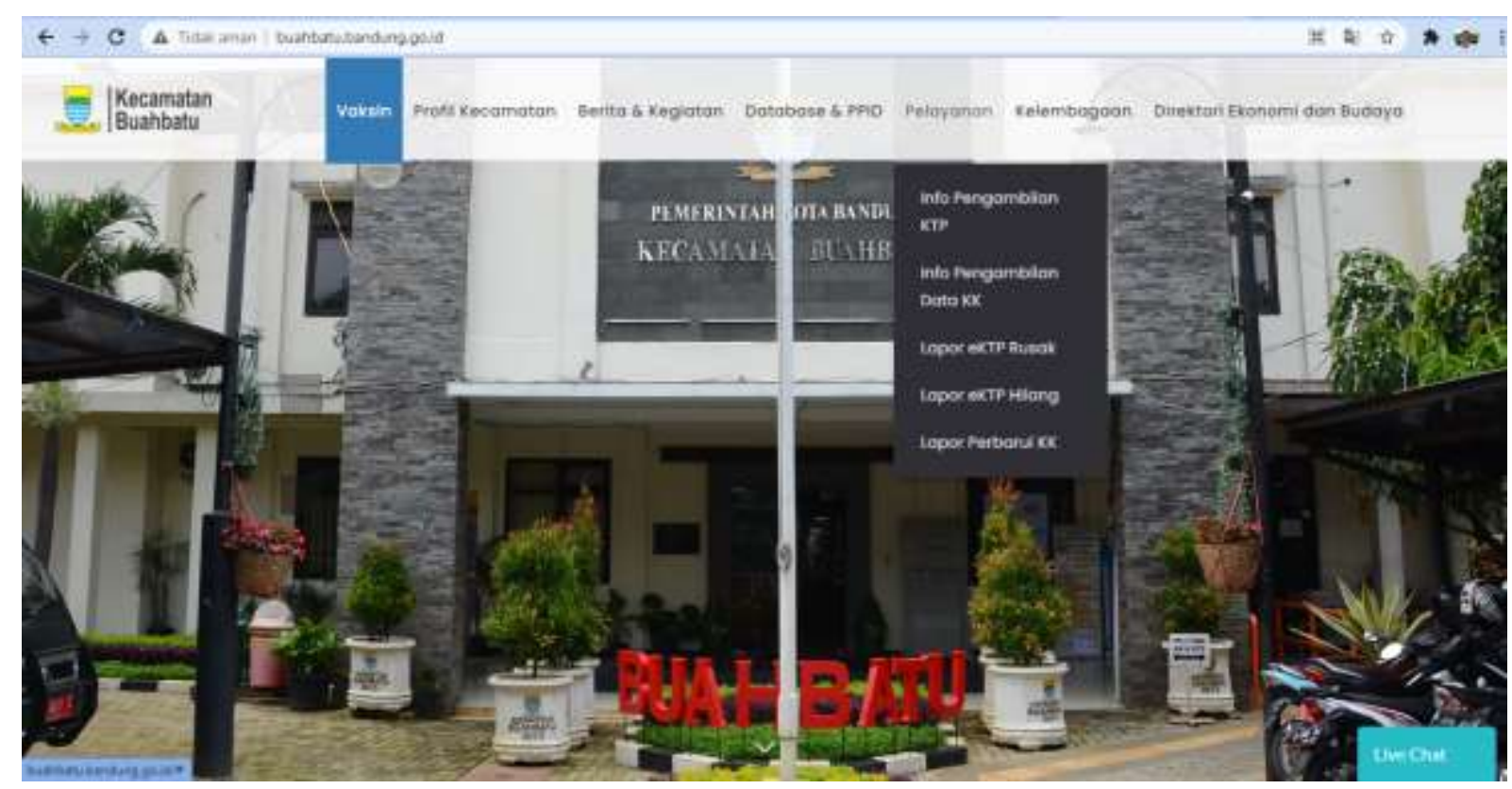

Figure 1. Development of New Features on the Website of Buah Batu District, 2021

The sustainability of community service activities has been manifested in the form of network and website maintenance by a team from Telkom University when necessary. In the field of marketing for the coming period, we will try to create a website that contains profiles of superior MSME products in Buah Batu District and at the same time become a platform for buying and selling online. Another form of program is that it can be realized in other forms of training needed by other target partners that have not been accommodated by community service this time.

To assess the program's execution, participants will be given a questionnaire detailing the advantages gained from participating in the training. Evaluation is performed to guarantee that all steps of the working process can be completed while meeting the goals that have been established (Richards \& Hemphill, 2018). Evaluation is carried out to ensure that all data is complete and in accordance with the needs and ensure that all functionality is as expected by the user. Results of interviews by resource persons to ensure that all methods and implementation are in accordance with the needs of the target partners. Evaluation is carried out to confirm each design conforms with the previously identified needs. Thus, the application can be directly built according to the design. Evaluation is carried out in the form of testing the integrated computer network and website by means of user representatives. This will be recorded and followed up immediately if errors and inappropriate functions are found. The purpose of evaluation is to ensure all users are involved in the implementation and training. The table below shows the evaluation and feedback or input from the target community on community service activities that have been carried out. 


\section{Activity Assessment Indicators}

This community service program is in accordance with the objectives of the activity itself.

This community service program is in accordance with the needs of the target community.

The timing of the implementation of this community service program has been relatively covered as needed.

Telkom University lecturers and students are friendly, fast and responsive during activities.

The local community accepts and expects the current and future Community Service activities of Telkom University.

The form of this collaborative community service activity consists of several forms of activity. Scientific training on computer networks, database management and network maintenance for IT staff in Buah Batu District can be integrated with marketing communication training and workshops on marketing tools for MSMEs which are expected to provide added value for MSME actors. Preparation of information systems and technology in the form of computer network integration and integrated websites with supporting applications makes it easier for users to access data and provide services to the community. The outputs resulting from the implementation of this community service are as follows:

1. The computer network system in Buah Batu District with the village and community service units has been integrated. Also the network can be well maintained and safe from hackers. In addition, through database management training, the database can be managed better.

2. Through integrated marketing communication training, it is hoped that the promotion of products produced by MSMEs in Buah Batu District will be better and more effective and will increase brand awareness of the potential consumers and tourists. Next, creating printed promotion designs in the form of brochures, flyers and offline and online catalogs or by building digital promotions for MSMEs in Buah Batu District, Bandung, is necessary.

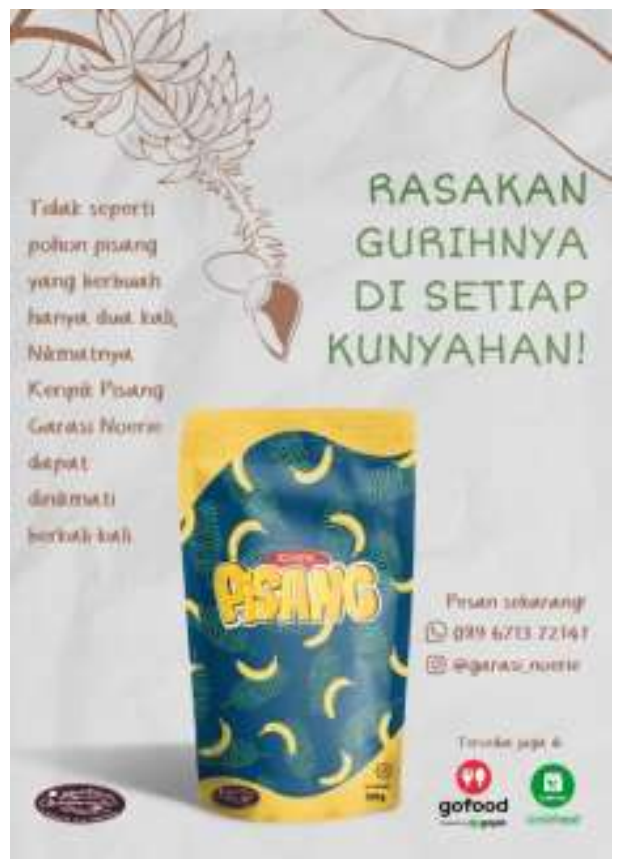

Figure 2. Example of MSME Product Poster Design in Buah Batu District, 2021 


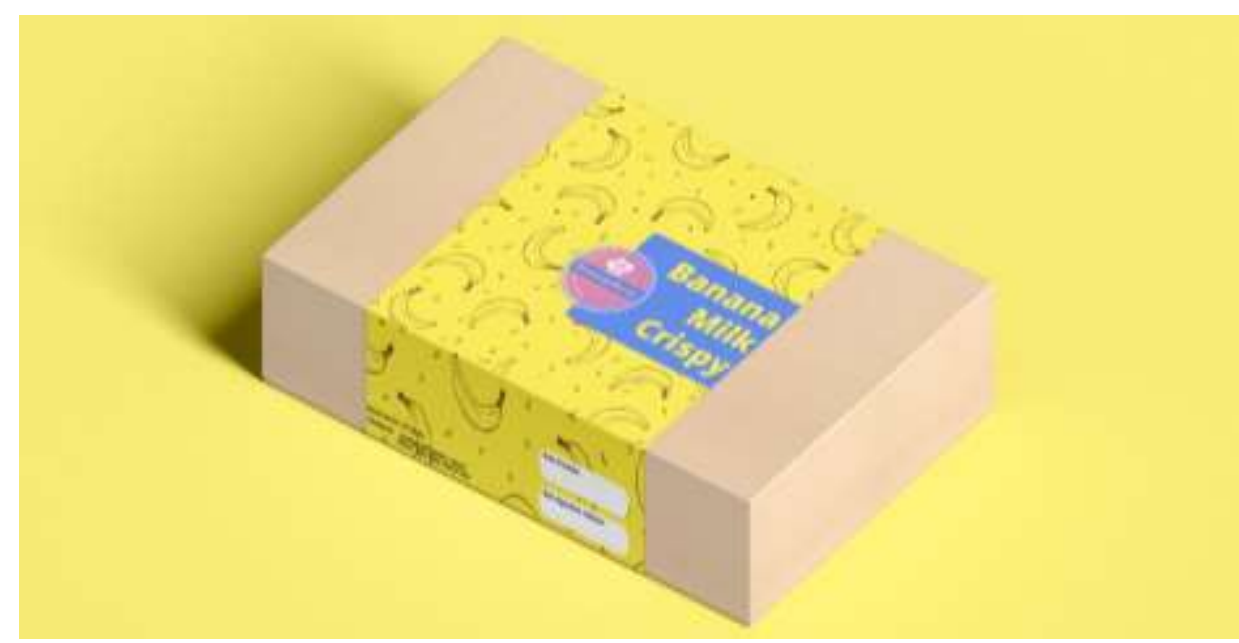

Figure 3. Examples of MSME Product Packaging in Buah Batu District, 2021

MSMEs in the Buah Batu area still have not had high competitiveness, with regard to internal elements such as manufacturing and processing, marketing, human resources, design, and technology. When competing in the global market, high competitiveness is required. This condition does provide opportunities as well as challenges for SMEs. Adopting information technology is one way to improve competitiveness. Despite the fact that the cost of information technology is decreasing and becoming more reasonable, most MSMEs remain costly items owing to financial constraints and a lack of experience in utilizing their own computers (Senarathna et al., 2018). With this requirement, not only the government, but all groups such as academics, practitioners, and students, are required to provide assistance. For example, if MSMEs need e-commerce to market products, of course only a few MSMEs are able to build it themselves, but buying products will certainly cost a lot of money.

\section{CONCLUSION}

Integrated Marketing Communication (IMC) is the basic concept for integrating and coordinating all of its communication channels to deliver a clear, consistent and powerful message. The adoption of this concept has been widely used by large companies as well as small companies, including MSMEs. The use of integrated marketing communications by MSMEs has not been maximized. This is because of the limited budget to carry out integrated marketing communication activities. Thus, the promotional activities carried out by MSMEs are still constrained by costs, so that only a few elements in integrated marketing communication can be applied by MSMEs, namely: advertising, publicity, sales promotion, and direct marketing. With limited funds, MSMEs can use promotional activities: distributing brochures, installing banners, giving discounts or free product samples, and online marketing using the internet.

Based on the results of the study, it is necessary to have an information technology-based support system as a medium that can be used by MSME actors to find information on supporters who have the necessary expertise. An information technology-based support system is needed as a medium that can be used by supporters (academics, practitioners and students) to find information on MSMEs that require their expertise. The support system needed is a system that can be accessed from anywhere and anytime.

This collaborative community service has been implemented in line with each team member's roadmap based on their individual skill groups. According to their individual capabilities, each team member has exchanged knowledge with target partners. The product provided to the target partner meets the demands of the target partner. For future community service activities, target partners must create a profile website for MSMEs in the Buah Batu District. The website can also be used as an online buying and selling portal, facilitating digital transactions other than through social media and marketplaces created in this community service. Furthermore, target partners require advanced network management training as well as the integration of public service apps and websites that have not been accommodated in this document. 


\section{REFERENCE}

Adhabi, E. A. R., \& Anozie, C. B. L. (2017). Literature Review for the Type of Interview in Qualitative Research. International Journal of Education, 9(3). https://doi.org/10.5296/ije.v9i3.11483

Archibald, M. M., Ambagtsheer, R. C., Casey, M. G., \& Lawless, M. (2019). Using Zoom Videoconferencing for Qualitative Data Collection: Perceptions and Experiences of Researchers and Participants. International Journal of Qualitative Methods, 18. https://doi.org/10.1177/1609406919874596

Autio, E. (2017). Strategic Entrepreneurial Internationalization: A Normative Framework. Strategic Entrepreneurship Journal, 11(3). https://doi.org/10.1002/sej.1261

Azungah, T. (2018). Qualitative Research Journal Article information: For Authors Qualitativeresearch: deductive and inductive approaches to data analysis. Thunderbird International Business Review, 62(4).

Badini, O. S., Hajjar, R., \& Kozak, R. (2018). Critical success factors for small and medium forest

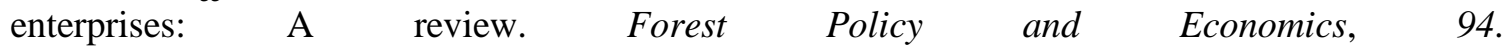
https://doi.org/10.1016/j.forpol.2018.06.005

Bellini, C. G. P., Pereira, R. de C. de F., \& Becker, J. L. (2020). Emergent customer team performance and effectiveness: An ex post facto study on cognition and behavior in enterprise systems implementation. Communications of the Association for Information Systems, 47(1). https://doi.org/10.17705/1CAIS.04726

Briandana, R., \& Dwityas, N. A. (2020). Conventional marketing communication tools for residential products in digital era. Technium: Social Science Journal, 14(1).

Camilleri, M. A. (2018). Market Segmentation, Targeting and Positioning. https://doi.org/10.1007/9783-319-49849-2_4

Castleberry, A., \& Nolen, A. (2018). Thematic analysis of qualitative research data: is it as easy as it sounds? In Currents in Pharmacy Teaching and Learning (Vol. 13, Issue 2). https://doi.org/10.1016/j.cptl.2020.12.001

Clegg, B. (2018). Perceptions of growth-impeding constraints acting upon SMEs' operations and the identification and use of transitionary paths to elevate them. International Journal of Operations and Production Management, 38(3). https://doi.org/10.1108/IJOPM-12-2015-0736

Ducange, P., Pecori, R., \& Mezzina, P. (2018). A glimpse on big data analytics in the framework of marketing strategies. Soft Computing, 22(1). https://doi.org/10.1007/s00500-017-2536-4

Eleboda, S. S. (2017). Sales Promotion as a Strategy in Service Marketing : Exploring the Believability Dilemma and Consumer Purchase Decision. American Journal of Marketing Research, 3(2).

Elihanov, V. G., \& Matygov, M. M. (2020). Types of online advertising and its features. TRENDS IN THE DEVELOPMENT OF SCIENCE AND EDUCATION. https://doi.org/10.18411/lj-12-2020-49

Elrawy, M. F., Awad, A. I., \& Hamed, H. F. A. (2018). Intrusion detection systems for IoT-based smart environments: a survey. In Journal of Cloud Computing (Vol. 7, Issue 1). https://doi.org/10.1186/s13677-018-0123-6

Evermann, J., Rehse, J. R., \& Fettke, P. (2017). Predicting process behaviour using deep learning. Decision Support Systems, 100. https://doi.org/10.1016/j.dss.2017.04.003

Farhana, N., Mohamed, B., Rahman, A., Ramez, M., \& Jounaidi, A. (2020). Direct Marketing Vs Creative Marketing: Evaluation and Analysis in Malaysia. In International Journal of Research and Scientific Innovation (IJRSI) |: Vol. VII.

Ferguson, M. A. (2018). Building theory in public relations: Interorganizational relationships as a public relations paradigm. Journal of Public Relations Research, 30(4). https://doi.org/10.1080/1062726X.2018.1514810

Fjeldstad, Ø. D., \& Snow, C. C. (2018). Business models and organization design. Long Range Planning, 51(1). https://doi.org/10.1016/j.lrp.2017.07.008

Fonseca, K. V. O., Kozievitch, N. P., Berardi, R. C. G., \& Schmeiske, O. R. M. (2020). Information Technology Macro Trends Impacts on Cities: Guidelines for Urban Planners. In Handbook of Smart Cities. https://doi.org/10.1007/978-3-030-15145-4_58-1

Fraccastoro, S., Gabrielsson, M., \& Pullins, E. B. (2021). The integrated use of social media, digital, and traditional communication tools in the B2B sales process of international SMEs. International Business Review, 30(4). https://doi.org/10.1016/j.ibusrev.2020.101776

Frustaci, M., Pace, P., Aloi, G., \& Fortino, G. (2018). Evaluating critical security issues of the IoT world: Present and future challenges. IEEE Internet of Things Journal, 5(4). 
https://doi.org/10.1109/JIOT.2017.2767291

Ganlin, P., Qamruzzaman, M. D., Mehta, A. M., Naqvi, F. N., \& Karim, S. (2021). Innovative finance, technological adaptation and smes sustainability: The mediating role of government support during covid-19 pandemic. Sustainability (Switzerland), 13(16). https://doi.org/10.3390/su13169218

Gao, H., Koch, C., \& Wu, Y. (2019). Building information modelling based building energy modelling: A review. In Applied Energy (Vol. 238). https://doi.org/10.1016/j.apenergy.2019.01.032

Gonzalez-Granadillo, G., Dubus, S., Motzek, A., Garcia-Alfaro, J., Alvarez, E., Merialdo, M., Papillon, S., \& Debar, H. (2018). Dynamic risk management response system to handle cyber threats. Future Generation Computer Systems, 83. https://doi.org/10.1016/j.future.2017.05.043

Harris, P. A., Taylor, R., Minor, B. L., Elliott, V., Fernandez, M., O’Neal, L., McLeod, L., Delacqua, G., Delacqua, F., Kirby, J., \& Duda, S. N. (2019). The REDCap consortium: Building an international community of software platform partners. In Journal of Biomedical Informatics (Vol. 95). https://doi.org/10.1016/j.jbi.2019.103208

Hartono, H., \& Haniya, R. D. (2018). Toward SMEs Engagement in Improving Creative Economic in Indonesia. Asia Proceedings of Social Sciences, 2(3). https://doi.org/10.31580/apss.v2i3.380

Hennink, M. M., Kaiser, B. N., \& Weber, M. B. (2019). What Influences Saturation? Estimating Sample Sizes in Focus Group Research. Qualitative Health Research, 29(10). https://doi.org/10.1177/1049732318821692

Hsu, T. C., Chang, S. C., \& Hung, Y. T. (2018). How to learn and how to teach computational thinking: Suggestions based on a review of the literature. Computers and Education, 126. https://doi.org/10.1016/j.compedu.2018.07.004

Hussain, S., Fangwei, Z., Siddiqi, A. F., Ali, Z., \& Shabbir, M. S. (2018). Structural Equation Model for evaluating factors affecting quality of social infrastructure projects. Sustainability (Switzerland), 10(5). https://doi.org/10.3390/su10051415

Jabbar, B., Diah, M. L. M., Othman, B., \& Hasan, Z. M. H. (2019). This study examines the antecedents and the effects of knowledge management and information technology in the manufacturing industry. International Journal of Psychosocial Rehabilitation, 23(2).

Kembau, A. S., Supit, V., \& Langi, C. (2019). Implementation of Integrated Marketing Communication (IMC) In Higher Education as An Adaptive Move in The Era of Industrial Revolution 4.0: A Case Study in Manado State Polytechnic. Journal of International Conference Proceedings, 2(2). https://doi.org/10.32535/jicp.v2i2.598

Key, T. M., \& Czaplewski, A. J. (2017). Upstream social marketing strategy: An integrated marketing $\begin{array}{llll}\text { communications } & \text { approach. } & \text { Business }\end{array}$ https://doi.org/10.1016/j.bushor.2017.01.006

Kuncoro, W., \& Suriani, W. O. (2018). Achieving sustainable competitive advantage through product innovation and market driving. Asia Pacific Management Review, 23(3). https://doi.org/10.1016/j.apmrv.2017.07.006

Leidner, D. E., Gonzalez, E., \& Koch, H. (2018). An affordance perspective of enterprise social media and organizational socialization. Journal of Strategic Information Systems, 27(2). https://doi.org/10.1016/j.jsis.2018.03.003

Li, Z., Barenji, A. V., \& Huang, G. Q. (2018). Toward a blockchain cloud manufacturing system as a peer to peer distributed network platform. Robotics and Computer-Integrated Manufacturing, 54. https://doi.org/10.1016/j.rcim.2018.05.011

Lu, Y., Wu, Z., Chang, R., \& Li, Y. (2017). Building Information Modeling (BIM) for green buildings: A critical review and future directions. Automation in Construction, 83. https://doi.org/10.1016/j.autcon.2017.08.024

Martin, R. (2017). INTEGRATED MARKETING COMMUNICATION AND LOYALTY MODEL. International Journal of Islamic Business Ethics, 2(1), 245. https://doi.org/10.30659/ijibe.2.1.245261

Moisander, J., Närvänen, E., \& Valtonen, A. (2020). Interpretive marketing research: Using ethnography in strategic market development. In Marketing Management. Routledge. https://doi.org/10.4324/9780203357262-22

Naum, O., Chyrun, L., Vysotska, V., \& Kanishcheva, O. (2017). Intellectual system design for content formation. Proceedings of the 12th International Scientific and Technical Conference on Computer Sciences and Information Technologies, CSIT 2017, 1. https://doi.org/10.1109/STCCSIT.2017.8098753

Peffers, K., Tuunanen, T., \& Niehaves, B. (2018). Design science research genres: introduction to the 
special issue on exemplars and criteria for applicable design science research. In European Journal of Information Systems (Vol. 27, Issue 2). https://doi.org/10.1080/0960085X.2018.1458066

Porcu, L., del Barrio-García, S., Kitchen, P. J., \& Tourky, M. (2020). The antecedent role of a collaborative vs. a controlling corporate culture on firm-wide integrated marketing communication and brand performance. Journal of Business Research, 119. https://doi.org/10.1016/j.jbusres.2019.10.049

Pramanik, S. A. K., \& Rakib, M. R. H. K. (2020). Conceptual analysis on tourism product and service promotion with special reference to Bangladesh. In Tourism Marketing in Bangladesh: An Introduction. https://doi.org/10.4324/9781003007241-11

Prasanna, R. P. I. R., Jayasundara, J. M. S. B., Gamage, S. K. N., Ekanayake, E. M. S., Rajapakshe, P. S. K., \& Abeyrathne, G. A. K. N. J. (2019). Sustainability of SMEs in the competition: A systemic review on technological challenges and SME performance. In Journal of Open Innovation: Technology, Market, and Complexity (Vol. 5, Issue 4). https://doi.org/10.3390/joitmc5040100

Prihadini, D., Nurbaity, S., Rachmadi, H., \& Krishantoro. (2020). The role of digital marketing in premoting private universities in the covid-19 pandemic period: A phenomenological approach. Technium Social Sciences Journal, 6.

Qian, C., Wu, C. F., Zhang, Z., \& Huang, H. Y. (2019). A study on the promotional mix of pre-service in the view of service design. Industrial Management and Data Systems, 119(8). https://doi.org/10.1108/IMDS-08-2018-0331

Qiu, T., Chen, N., Li, K., Atiquzzaman, M., \& Zhao, W. (2018). How can heterogeneous internet of things build our future: A survey. IEEE Communications Surveys and Tutorials, 20(3). https://doi.org/10.1109/COMST.2018.2803740

Radianti, J., Majchrzak, T. A., Fromm, J., \& Wohlgenannt, I. (2020). A systematic review of immersive virtual reality applications for higher education: Design elements, lessons learned, and research agenda. Computers and Education, 147. https://doi.org/10.1016/j.compedu.2019.103778

Razak, M., Hidayat, M., Launtu, A., Kusuma Putra, A. H. P. A., \& Bahasoan, S. (2020). Antecedents and consequence of brand management: empirical study of Apple's brand product. Journal of Asia Business Studies, 14(3). https://doi.org/10.1108/JABS-01-2019-0030

Richards, K. A. R., \& Hemphill, M. A. (2018). A practical guide to collaborative qualitative data analysis. Journal of Teaching in Physical Education, 37(2). https://doi.org/10.1123/jtpe.20170084

Rodríguez-Soler, J., \& Brunet Icart, I. (2018). Between vocational education and training centres and companies: study of their relations under the regional innovation system approach. Studies in Continuing Education, 4O(1). https://doi.org/10.1080/0158037X.2017.1343239

Sari, N. M. W., Suwarsinah, H. K., \& Baga, L. M. (2016). Pengaruh Karakteristik Kewirausahaan terhadap Kinerja Usaha Mikro, Kecil dan Menengah(UMKM) Gula Aren di Kabupaten Lombok Barat. Jurnal Penyuluhan, 12(1). https://doi.org/10.25015/penyuluhan.v12i1.11320

Schmeltz, L., \& Kjeldsen, A. K. (2019). Co-creating polyphony or cacophony? A case study of a public organization's brand co-creation process and the challenge of orchestrating multiple internal voices. Journal of Brand Management, 26(3). https://doi.org/10.1057/s41262-018-0124-2

Senarathna, I., Wilkin, C., Warren, M., Yeoh, W., \& Salzman, S. (2018). Factors that influence adoption of cloud computing: An empirical study of Australian SMEs. Australasian Journal of Information Systems, 22. https://doi.org/10.3127/ajis.v22i0.1603

Sulaeman, M., \& Kusnandar, H. F. (2020). Integrated Marketing Communication Model in Shaping Brand Equity and Business Performance in the Creative Industries of Embroidery Sector. Budapest International Research and Critics Institute (BIRCI-Journal): Humanities and Social Sciences, 3(4). https://doi.org/10.33258/birci.v3i4.1444

Ul Hassan, N., Yuen, C., \& Niyato, D. (2019). Blockchain Technologies for Smart Energy Systems: Fundamentals, Challenges, and Solutions. IEEE Industrial Electronics Magazine, 13(4). https://doi.org/10.1109/MIE.2019.2940335

Urquhart, L., \& McAuley, D. (2018). Avoiding the internet of insecure industrial things. Computer Law and Security Review, 34(3). https://doi.org/10.1016/j.clsr.2017.12.004

Vătămănescu, E. M., Cegarra-Navarro, J. G., Andrei, A. G., Dincă, V. M., \& Alexandru, V. A. (2020). SMEs strategic networks and innovative performance: a relational design and methodology for knowledge sharing. Journal of Knowledge Management, 24(6). https://doi.org/10.1108/JKM-012020-0010

Villanova, D., Bodapati, A. V., Puccinelli, N. M., Tsiros, M., Goodstein, R. C., Kushwaha, T., Suri, R., 
Ho, H., Brandon, R., \& Hatfield, C. (2021). Retailer Marketing Communications in the Digital Age: Getting the Right Message to the Right Shopper at the Right Time. Journal of Retailing, 97(1). https://doi.org/10.1016/j.jretai.2021.02.001

Wandasari, Y., Kristiawan, M., \& Arafat, Y. (2019). Policy evaluation of school's literacy movement on improving discipline of state high school students. International Journal of Scientific and Technology Research, 8(4).

Wetik, J. D., Saleh, A., \& Asngari, P. S. (2019). Komunikasi Pemasaran Terpadu dalam Mengembangkan Kapasitas Petani Padi di Provinsi Banten. Jurnal Penyuluhan, 15(1). https://doi.org/10.25015/penyuluhan.v15i1.19468

Wilson, V., \& Makau, C. (2018). ONLINE MARKETING USE: SMALL AND MEDIUM ENTERPRISES (SMEs) EXPERIENCE FROM KENYA. Orsea Journal, 7(2). 